ABSTRACT

Do You Feel the Same? Different Dominants of Theatrical Experience

The aim of this article is to present an exploratory study of reception research of theatrical experiences of general audiences of spoken theatre performances in

Tartu, Estonia. The research is based on a quantitative survey of the audiences

of eight spoken theatre performances. Factor analysis is used to assemble 24 different performance characteristics into five factors: Aesthetic, Entertainment, Personally Challenging, Complexity and Conventionality Factor. The factor analysis also points out some possible overlaps (characteristics that could be included into different factors at the same time) between factors, particularly between the Aesthetic and Personally Challenging Factor. These overlaps could be explained by (1) the limits of the quantitative survey, (2) the language and (3) the performances included in the survey. The overlaps, from the perspective of the viewer being inspired, challenged and excited by the performance, are due to the reason

that the performances are personally touching as well as demanding and are performed by skilful performers. The article discusses the point that aesthetically challenging performances can be thematically or artistically demanding for the viewer, if the viewer has a personal relationship to the theme.

Keywords: theatrical experience, reception research, factor analysis, exploratory research, STEP, experiential value.

BIOGRAPHY

Hedi-Liis Toome is a PhD student of theatre studies at the Institute of Cultural Research and Fine Arts at the University of Tartu, Estonia. In her PhD thesis she studies the functioning of theatre in Tartu and is doing research not only on the reception, but also on the production and distribution of theatre. Since 2010, she has been a member of the international research group Project on European Theatre Systems (STEP). She has also lectured at the University of Tartu and at the Estonian Academy of Arts and has worked on administrative positions in different theatre organisations. hediliis@gmail.com 


\section{Do You Feel the Same? Different Dominants of Theatrical Experience ${ }^{1}$}

\section{HEDI-LIIS TOOME}

\section{INTRODUCTION}

What do people encounter during a theatre performance, "what kind of emotional reactions and what kind of thoughts occur while the spectator is watching stage activities" 2 are relevant questions when studying the micro-aspects of reception research. There are different approaches for how to study the reception of audiences and researchers have, therefore, introduced a range of approaches for investigating theatrical experiences. Peter Eversmann has pointed out the four dimensions of theatrical experience (perceptual, cognitive, emotional and communicative). ${ }^{3}$ Marju Lauristin and Peeter Vihalemm have distinguished between three types of engagement with a performance: intellectual, entertaining and emotional. ${ }^{4}$ Hans van Maanen indicates three types of aesthetical experience: decorative, comfortable and challenging. ${ }^{5}$ In arts marketing, the focus is on the relationship between the experience of theatre and the overall quality of the performances. ${ }^{6}$ All these studies have tried to model the reception processes and this article seeks to contribute to this type of research.

The study presented in this article is based on a survey conducted among general audiences and concentrates on the experiences of the spectators of spoken theatre performances of Tartu. The research is a part of the international research group STEP (Project on European Theatre Systems). The aim of the research group is to study how theatre functions in different (but somewhat comparable) cities in smaller European countries. ${ }^{7}$ The research follows the idea that the values produced and distributed by the theatre and realised by audiences determine the functioning of theatre on a personal and societal level. ${ }^{8}$

Therefore, to understand the functioning of theatre on a city level, the production, distribution and reception of theatre has been studied. As mentioned above, this article investigates the reception of theatre in Tartu. ${ }^{9}$ The aim of this article is to present an exploratory study of reception research of theatrical experiences to see how the theoretical frameworks used to build up the research are in line with the results of a particular reception research and if and why the results differ. Secondly, the article points out some methodological aspects of reception research.

The theoretical framework is given at the beginning of the article. Then, the methodology is introduced and the idea and results of factor analysis are presented. Next, the overlaps between factors are pointed out and explained with the help of particular performances whose audiences were included in the survey.

\section{THE THEORETICAL BASE OF THE RESEARCH}

The research presented in this article is based on the theories of two Dutch theatre researchers.

Peter Eversmann ${ }^{10}$ introduces the following four dimensions of aesthetic experience of theatre, based on conceptions developed by Mihaly Csikszentmihalyi and Rick E. Robinson who have studied the aesthetic experience of the plastic arts. ${ }^{11}$ 
1. A perceptual dimension, where one is concerned with things like composition, structure, form, balance, etc. It is experiencing without interpreting or attaching meaning to the experience and is usually purely physical.

2. An emotional dimension, which is, firstly, related to ones feeling toward the fictional world and, secondly, to being physically present at the theatre. These feelings can also intrigue or confuse, but should usually transform negative feelings into positive ones.

3. A cognitive dimension, which is related mostly to one's knowledge of theatre, to the recognition of familiar circumstances (for example identifying oneself with the characters or subject matter), and to being able to relate - and also relating - the things seen on the stage to one's own life.

4. A communicative dimension is integrated in the other three dimensions because they are all aspects of communication between the performance and the audience. In the case of theatre, in addition to personal reception, there is also the joint reception of the whole audience watching the same performance at the same time.

Even though Eversmann defines the dimensions separately, he argues that they are not separate entities, but rather integrated factors in a complex whole.

Hans van Maanen has also defined three types of theatrical experiences, distinguishing between decorative, comfortable and challenging artistic experience. $^{12}$

1. The decorative is "the experience of the form that does not seek a meaning".

2. The comfortable (non-artistic) is "the experience of form that can be understood by means of familiar perceptual schemata".

3. The challenging (artistic) experience is "the experience of form that calls for a reassessment of one's perceptual schemata". ${ }^{13}$ The experience is challenging, when it produces new representations for the audience member.

While Eversmann is interested in what happens during an aesthetic encounter, Van Maanen's focus is the effect of this encounter, i.e. in the experiential values the encounter brings forth in the audience member and whether it prompts any change to the perception of the spectator.

Both Van Maanen and Eversmann argue that theatrical experience is not isolated from the context (direct and indirect) in which the experience takes place. Both authors place the reception of the performance into the frame of the Theatrical Event. ${ }^{14}$ The Theatrical Event is a concept consisting of four components: Theatrical Playing - Playing Culture - Cultural Context - Contextual Theatricality that are tightly interwoven and simultaneously active during the theatrical encounter between spectator and a stage. ${ }^{15}$

In this article, it will be shown in what ways the dimensions and the types of aesthetic experience operate together in the process of reception.

\section{METHODOLOGY}

The study presented here is based on a quantitative survey of the audiences of eight spoken theatre performances (described later in the article) staged in Tartu, in theatre Vanemuine and in Tartu New Theatre (TNT).

The visitors to these eight productions were presented with a list of characteristics and were asked to consider how they would describe the performances on a scale from 1 (not at all) to 6 (very much so). ${ }^{16}$ Theoretically, the characteristics, based on the works of Eversmann and Van Maanen, could be divided into six clusters:

1. Forms and Skills: skilful, beautiful to look at, full of new images;

2. Emotional Engagement: impressive, exciting, surprising, comforting, satisfyingly complete, painfully touching;

3. Cognitive Engagement: inspiring, recognizable, confrontational, challenging, conventional, superficial, boring;

4. Complexity: complicated, demanding for you personally, easy to follow;

5. Entertainment: relaxing, good fun, funny;

6. Relevance: relevant for you personally, socially relevant.

The first cluster, Forms and Skills, refers to values such as the experience of beauty, newly experienced images and the certain level of skil- 
fulness performers display. The clusters Emotional and Cognitive Engagement have their roots in the emotional and cognitive dimensions of the theatrical experience discerned by Eversmann. ${ }^{17}$ The fourth cluster, Complexity, is related to the distinction between comfortable and challenging experience. ${ }^{18}$ Entertainment is often seen as being characteristic of more comfortable experiences and therefore used as a separate category. Finally, the experienced Relevance of the performance refers to its relevance for the real life of spectators, either on a personal or on a societal level. ${ }^{19}$

\section{OVERVIEW OF THE THEATRES}

Vanemuine is the leading theatre of Tartu. Among the permanently situated theatres in Tartu, Vanemuine produces $84 \%$ of the city's performances and receives $93 \%$ of Tartu's theatre visits compared to TNT, which produces $8 \%$ of performances and receives $2 \%$ of the visits. ${ }^{20}$

Vanemuine has a permanent troupe of twenty six actors and two directors, in addition they often use guest directors. It is the only theatre in Estonia to produce music, dance and spoken theatre and has three different venues - a 700-seat and a 400-seat proscenium stage and a black box for a maximum of 250 people.

In terms of theatrical style, Vanemuine represents a quite conservative theatre, staging mainly text based productions (both contemporary Estonian and foreign authors) with the emphasis on good ensemble acting. The aim of the theatre is to offer a wide and versatile repertoire for different target groups living in the city and county of Tartu. ${ }^{21}$ The aim of appealing to many different groups of people is also visible through the performances that were chosen for the audience research. The performances under examination form a cross-section of the repertoire of spoken theatre. Vanemuine does not stage risky projects, but is quite audience oriented in their repertoire planning. The latter is explained by the need to keep up a theatre with three different buildings and a lot of workforce which means that costs on administration and personnel are considerable. The state subsidy forms about $65 \%$ of the theatre's annual budget, the rest is dependent on box office income.

TNT is a small project based theatre with a 100seat black box and without a permanent troupe. The style of the theatre is largely determined by their artistic and managing director Ivar Póllu, a former theatre researcher and dramaturge. This theatre produces performances based on devising or often the text is written by the same person who directs the play. TNT is the only company outside of the capital city Tallinn to produce contemporary dance alongside spoken theatre. TNT is held in high regard by the critics and has won many theatre awards in Estonia in recent years. Their aim is not to compete with Vanemuine, but rather to offer something different from the larger theatre's repertoire. In fact, the actors of Vanemuine are sometimes featured in the performances of TNT, which means that the two theatres have a somewhat collaborative relationship and that the actors with a permanent income from Vanemuine could be looking for artistic challenges at TNT. In 2013, the state subsidy and project based subsidy formed $50 \%$ of the theatre's budget, which is a major rise compared to the years 2012 (30\% of the budget was through state subsidies) and 2011 (only 20\%). ${ }^{22}$

\section{OVERVIEW OF THE PERFORMANCES}

The eight performances included in the research were chosen in order to be representative of a season of spoken theatre in Tartu. Two performances were from TNT and six from Vanemuine.

Both of the performances of TNT were written and staged by the artistic and managing director of the theatre, Ivar Póllu, and both of them depicted the theatrical history of Tartu. The first, Ird, K., was about one of the most iconic and controversial theatre directors of Estonia, Kaarel Ird (1909-86), a fierce communist, yet a supporter of the Estonian theatre renewal of the 1970s. ${ }^{23}$ Ird was presented as an old man looking back on some of the episodes of his life. Despite the well-known real life based characters, the performance offered many dreamlike scenes such as Ird leaving for space at the end of the performance. 
The second performance, The Beatles of Vanemuine was about the aforementioned theatre renewal of the 1970s. While Ird, K. had recognizable characters and a story line, The Beatles of Vanemuine was a postdramatic performance that consisted of short scenes, which only vaguely referred to real people and events of the 1970s as well as referring to The Beatles through the play's musical aspect and wigs.

Among the six performances of Vanemuine, four were staged in a more realistic style and two in more playful style. Calendar Girls, a comedy based on the world famous British movie of the same name was staged according to the storyline and followed the realistic style of the movie. The second comedy, $A$ Behanding in Spokane, written by Irishman Martin McDonagh (an author very familiar to Estonian audiences) is a black comedy and could also be considered a performance staged in a realistic style.

The Purge, a play by Sofi Oksanen, is a rewriting of her prize-winning novel of the same name. ${ }^{24}$ The story takes place in Estonia during the 1990s with flashbacks to the 1950s. It deals with the controversial times of living and surviving under the violence of the Communist era as well as pointing to more universal problems of women being victims of violence and trafficking. The novel caused very diverse reactions in Estonia because of the way Estonians were depicted (as collaborators of the communists versus good nationalists), even though Oksanen herself stated that the novel is more about violence against women than about the Estonians per se. However, in Vanemuine, the themes concerning Soviet Estonia were depicted in a black and white scale supported by a very realistic, yet paperboard set design. Oblomov, based on the novel by Ivan Goncharov, was a traditionally staged text-based costume drama. Both of these two productions were staged in realistic style, putting more emphasis on the presentation of text than on the form of the performance.

One of the more playful performances was Man's Best Friends, an intelligent comedy, written and directed by Rein Pakk, talking about the love triangle between a man, a woman and a talking dog. The storyline was universal, questioning the ways of human communication, stereotypes and ways of finding real love in consumer society. The set design was very minimalistic and the director used shadow theatre to communicate some parts of the storyline.

The last of the six performances, Career, was written and directed by a promising, young Estonian director, Uku Uusberg. Uusberg has, so far, staged his own texts in such a way that, in the first instance, they seem very recognizable and take off from everyday life situations, but very soon, the audience realizes there are more and more drifts towards a positive abnormity. Playing with the Estonian language and humour has always been a part of Uusberg's texts and performances.

In general, except The Beatles of Vanemuine, all the other performances can be considered dramatic theatre with an intelligible storyline and character development. Only Calendar Girls and A Behanding in Spokane can be labelled as comedies, but Man's Best Friends and The Career had comic elements as well. The Purge, Ird, $K$. and The Beatles of Vanemuine all dealt with Soviet times and the past, a subject matter still considered an interesting topic by the audiences.

\section{THE RESPONDENTS}

The questionnaire was distributed in Vanemuine and TNT in September and October 2012. With the help of theatre studies students, e-mail addresses from audience members were gathered before the beginning and during the break of the performances in the lobbies of the theatres. For those without an e-mail address, a paper questionnaire with a stamped envelope was distributed so the respondent could send in the filled questionnaire by mail later. The respondents were picked randomly from the audience who arrived at the theatre. A representative cross section of people based on sex or age was not important for this research. Altogether, 1401 people responded to the questionnaire (around $19 \%$ of all the visitors of an average theatre season for TNT and Vanemuine together). 792 of these responses are integrated into this particular article. From these 792 respondents $21.7 \%$ were male and $78.3 \%$ female, the average age of the visitors was 36. $69.7 \%$ of the visitors had a higher education, $80.3 \%$ lived in the city or county of Tartu. 


\section{FACTOR ANALYSIS}

Factor analysis is a method of data reduction by seeking underlying unobservable (latent) variables that are reflected in the observed (manifest) variables. There are several methods and variates of rotations used in factor analysis. ${ }^{25}$ In this research, the principal axis factoring method is used and the data is rotated with the Varimax method. ${ }^{26}$ The Institute of Digital Research and Education emphasises the relativity aspect of the factor analysis: "Given the number of factor analytic techniques and options, it is not surprising that different analysts could reach very different results analysing the same data set. However, all analysts are looking for a simple structure. A simple structure is a pattern of results such that each variable loads highly onto one and only one factor." ${ }^{27}$ This means that factor analysis is a statistical method, which emphasizes the interpretation of factors and is therefore relatively open to different interpretations, and could, thus, be questioned by other researchers.

\section{RESULTS:THE FIVE FACTORS}

In this research, factor analysis was used to assemble 24 different performance characteristics into factors that bring out the different dominants of the performances and how the audience members experience the performances. All responses to the different performances were combined together when conducting the factor analysis because the aim of the research is to make some theoretical generalisations about the dominants of aesthetical experiences people have acknowledged in the theatrical encounters, not to study how different performances are experienced by spectators. ${ }^{28}$

The factor analysis is a method of data reduction that was conducted on the data three times: first, the statistical program SPSS determined the number of factors (the program suggested 4), the next two times number of factors (respectively 5 and 3 as one more and one less factor that the program suggested) were determined by the researcher. Being quite an open method, the final number of factors should be determined by the researcher based on the possible meaningful interpretation on the chosen number of factors. In this research, the five fac- tor model was chosen because of its relevancy and possible connections to the theories explaining the reception of theatre. The five factor model already points out that the results of this survey are not totally compliant with the six clusters drawn from the theory. Thus, the theory and empirical data collected in Tartu overlap only partly.

The five factors are presented in Figure 1. The characteristics grouped together and presented in bold in the same column form one factor. The numbers not in bold have such a small factor loading that they are not included into this particular factor, but to another factor into which their factor loading is bigger. A factor loading (maximum is 1) shows how strongly the characteristic is bound into the factor. The higher the factor loading, the more this characteristic defines the factor (the biggest range between factor loadings is for the Aesthetic Factor from .378 to .746 , see Figure 1). Each factor has to be interpreted and described by the researcher.

The first factor (Fig. 1) contains the following characteristics: impressive, skilful, not superficial, not boring, complete and full of new images. This factor could be called the Aesthetic Factor, because the variables are mostly related to the everyday notion of good theatrical performance that could be generalized as "a good, enjoyable, professionally done production". The opposite factor loadings of boring and superficial in this factor show that the performances are seen as being interesting and having meaning.

The second factor contains characteristics like good fun, funny, relaxing and beautiful to look at, and is named the Entertainment Factor. Especially good fun and funny give the biggest dominant in this factor. It means that having a fun time is identified the most with funny, i.e. worth laughing at. It is not particularly surprising that relaxing is in this factor and not in any other - it means that relaxation is first of all related to entertainment and having fun.

The third factor includes personally relevant, painfully touching, personally demanding, challenging, exciting, inspiring, socially relevant and comforting. This could be named the Personally Challenging Factor because most of the characteristics defining this factor demand a certain personal and emotional connection between the performance 


\begin{tabular}{|c|c|c|c|c|c|}
\hline & \multicolumn{5}{|c|}{ Factor } \\
\hline & $\begin{array}{l}\text { Aesthetic } \\
\text { Factor }\end{array}$ & $\begin{array}{c}\text { Entertainment } \\
\text { Factor }\end{array}$ & $\begin{array}{c}\text { Personally } \\
\text { Challenging } \\
\text { Factor }\end{array}$ & $\begin{array}{l}\text { Complexity } \\
\text { Factor }\end{array}$ & $\begin{array}{c}\text { Conventionality } \\
\text { Factor }\end{array}$ \\
\hline Impressive & .746 & .224 & .350 & .098 & .009 \\
\hline Skilful & .743 & .223 & .302 & .126 & .005 \\
\hline Superficial & -.714 & .068 & -.051 & .043 & .149 \\
\hline Boring & -.582 & -.198 & -.095 & .133 & .163 \\
\hline Complete & .540 & .224 & .211 & -.143 & .184 \\
\hline Surprising & .408 & .275 & .253 & .407 & -.219 \\
\hline $\begin{array}{l}\text { Full of new } \\
\text { images }\end{array}$ & .378 & .256 & .294 & .255 & -.085 \\
\hline God fun & .144 & .883 & -.093 & -.054 & -.061 \\
\hline Funny & .083 & .847 & -.104 & -.076 & -.051 \\
\hline Relaxing & .294 & .635 & .093 & -.096 & .051 \\
\hline $\begin{array}{l}\text { Beautiful to look } \\
\text { at }\end{array}$ & .430 & .495 & .242 & .054 & .088 \\
\hline $\begin{array}{l}\text { Personally } \\
\text { relevant }\end{array}$ & .232 & .006 & .696 & .088 & .082 \\
\hline $\begin{array}{l}\text { Painfully } \\
\text { touching }\end{array}$ & .272 & -.293 & .658 & .197 & .020 \\
\hline $\begin{array}{l}\text { Personally } \\
\text { demanding }\end{array}$ & .040 & -.216 & .605 & .355 & -.014 \\
\hline Challenging & .380 & .231 & .589 & .209 & -.033 \\
\hline Exciting & .421 & .212 & .515 & .004 & .052 \\
\hline Inspiring & .493 & .358 & .497 & .186 & .034 \\
\hline Socially relevant & .415 & -.073 & .485 & .151 & .159 \\
\hline Comforting & .044 & .393 & .477 & -.042 & .114 \\
\hline Complicated & .099 & -.169 & .134 & .745 & -.103 \\
\hline Controversial & -.100 & .002 & .225 & .463 & .018 \\
\hline Easy to follow & .118 & .422 & .047 & -.443 & .307 \\
\hline Conventional & -.182 & .012 & .004 & -.041 & .707 \\
\hline Recognizable & .053 & -.002 & .120 & -.090 & .649 \\
\hline
\end{tabular}

Fig. 1. The five factors and factor loadings.

and the respondent and refer to the need to confront the performance. At the same time, one sees that the factor also includes characteristics like exciting and inspiring that refer to the positive touch that the performance is able to bring out in the audiences. This is the factor that conveys the most personal approach to the performances.

The forth factor includes characteristics like complicated, controversial and not easy to follow. It is named the Complexity Factor because all the characteristics refer to certain difficulties in understanding the performance.
The last factor contains characteristics such as conventional and recognizable and could be named the Conventionality Factor. These two characteristics are linked in the eyes of audiences, i.e. conventional performances are almost always recognizable and recognisability is closely combined with conventionality. Thus, recognisability is mostly connected to the traditional and familiar style of theatre and is understood as the feature of the performance, not as the possibility to recognize oneself in the performance.

Even though the empirical results show that the- 
oretical clusters are not one to one with the factors, the clusters, as well as the dimensions (Eversmann) and types (van Maanen) of aesthetic experience are likewise present in the factors. Figure 2 illustrates the relationship between the clusters and the factors. The five factors - Aesthetic, Entertainment, Personally Challenging, Complexity and Conventionality Factor - and their contents are relatable, but not totally compatible with the six methodological clusters.

The Entertainment and Complexity Factor are compatible with the Entertainment and Complexity cluster. The two characteristics included in the Conventionality factor are both part of the Cognitive engagement cluster, which means that the recognisability of the performance is realized through cognitive engagement. Skills and forms are related to the Aesthetic Factor, which means that the form of the performance (the acting and set design) is clearly connected to the aesthetics of the performance and not so much to the themes presented on stage that should be experienced through cognitive and emotional engagement. Relevance, again, is connected to the Personally Challenging Factor, which is not surprising because a performance can be personally relevant if the spectator develops a personal connection to the performance.

Cognitive and Emotional engagement dissolve into the Aesthetic and Personally Challenging Factor, which means that the relationship between these factors are the most complex. It appears, though, that the two characteristics that, among others things, were meant to describe cognitive en- gagement (conventional, recognizable) create quite an independent Conventionality Factor.

Even though the simple structure of factor analysis means that one variable loads only in one factor, the results of this factor analysis show that some of the characteristics included in one factor have loadings that enable one to connect the characteristics to some other factors as well - for example the factor loading for surprising in the Aesthetic Factor is .408, but in the Personally Challenging Factor it would be .407 . If surprising were to be connected to the Personally Challenging Factor instead of the Aesthetic Factor, the essence of these two factors could change and they could be interpreted differently. Only the Conventionality Factor includes characteristics that could not be related to any other factor - it is due to the fact that the two characteristics included in the factor have high factor loadings (.707 and .649) and for this reason the Conventionality Factor is left out of the following part of the analysis.

Figure 3 shows the characteristics that could be included in more than one factor. The ruled out characteristics are the ones that could be removed from the existing factors and the arrows point into which factors these characteristics would be included.

The characteristics exciting, inspiring and socially relevant (currently part of the Personally Challenging Factor) could be included in the Aesthetic Factor, in which case the latter could be changed to the Aesthetically Challenging Factor instead of being just aesthetic. If these three characteristics were removed from the Personally Challenging Factor, the

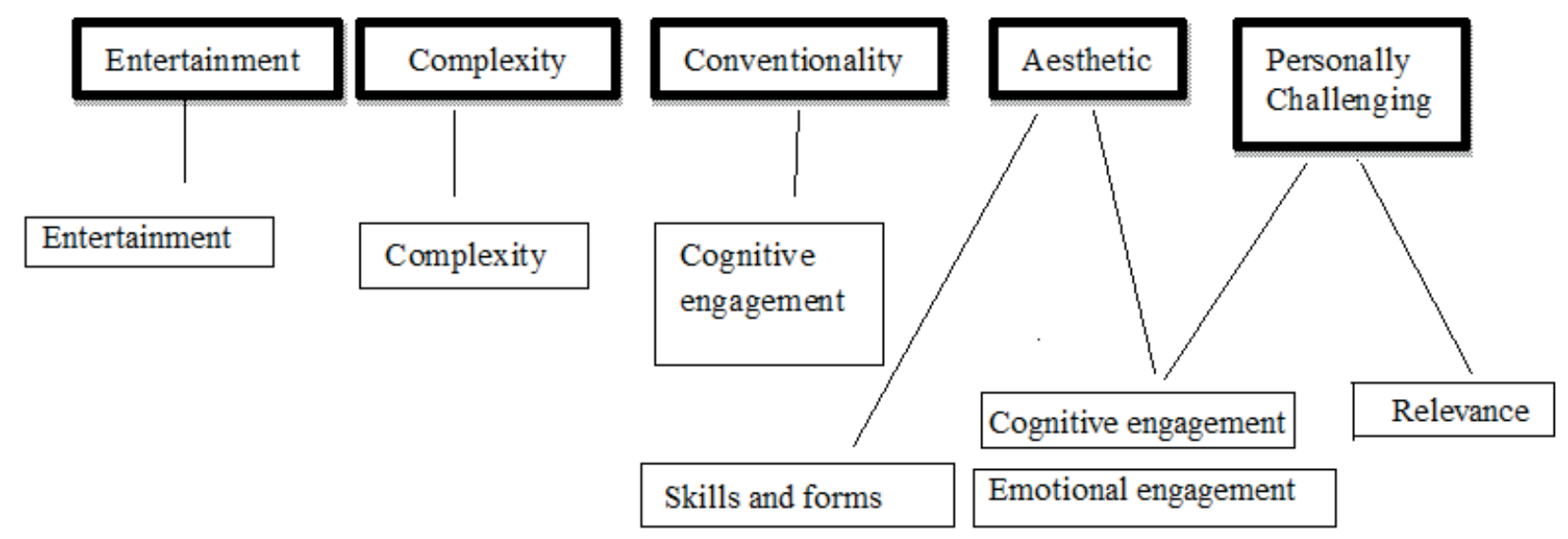

Fig. 2. The computability of factors and clusters. 
latter would still maintain its essence, but the emphasis would be more on the personal connection to the performance and less on the aesthetic and social aspects.

Surprising could be related to the Complexity Factor. Removing surprising from the Aesthetic Factor does not change the meaning of the factor a lot. Without surprising, the Aesthetic Factor would only lose some of its reference to experiencing something new or different but this would be compensated by the new characteristics like exciting and inspiring. Adding surprising to the Complexity Factor gives it a more positively challenging aspect, meaning that the viewer is bewildered, but yet surprised by the themes or forms shown on the stage.

Comforting can also relate to the Entertainment Factor. If, in the Personally Challenging Factor, comforting adds a soothing and balancing effect to the personally demanding experience, in the Entertainment Factor, the comfort comes from the possibility of being able to laugh and have fun.

The last overlap between factors is related to the easy to follow. When included in the Entertainment Factor, it adds some more easiness to the factor and would make it more about relaxation than having something to laugh about on the stage.

In general, it can be concluded that the relocation of the characteristics does not change the basic ideas of the five factors acquired, but points to the connections between the factors and opens up some possible connotations of the different dominants of the reception process. Figure 4 maps and visualizes the four factors and the characteristics (the overlaps) that operate as connecting points between the factors.

As appears from Figure 4, there are most connections between the Aesthetic and Personally Challenging Factors. These overlaps described above could be explained by three aspects: (1) the limits of the quantitative survey, (2) the language and (3) the performances included in the survey.

A quantitative questionnaire enables the researcher to rate the given characteristics on a numerical scale, but does not show exactly how the respondents interpreted the different characteristics. The results of the statistical analysis are interpreted by a subjective researcher, meaning that the researcher gives a deeper meaning to the different characteristics without knowing how they were understood by the spectators. For example, challenging is not a

\begin{tabular}{|c|c|c|c|}
\hline $\begin{array}{l}\text { Aesthetically } \\
\text { Challenging Factor }\end{array}$ & Entertainm ent Factor & $\begin{array}{l}\text { Person ally Challenging } \\
\text { Factor }\end{array}$ & $\begin{array}{l}\text { Complexity } \\
\text { Factor }\end{array}$ \\
\hline $\begin{array}{l}\text { Impressive }(.746) \\
\text { Skilful }(.743) \\
\text { Superficial }(-.714) \\
\text { Boring }(-.582) \\
\text { Complete }(.540) \\
\text { Surprising }(.408) \\
\text { Full of new images } \\
\text { (.378) } \\
\text { Exciting }(.421) \\
\text { Inspiring (.4984 } \\
\text { Socially relevant }(.4 \\
\text { Beautiful to look at } \\
\text { (.430) }\end{array}$ & $\begin{array}{l}\text { God fun (.883) } \\
\text { Funny (.847) } \\
\text { Relaxing (.635) } \\
\text { Beautiful to look at } \\
\end{array}$ & $\begin{array}{l}\text { Personally relevant (.696) } \\
\text { Painfully touching (.658) } \\
\text { Personally demanding } \\
(.605) \\
\text { Challenging (.589) } \\
\text {. }\end{array}$ & $\begin{array}{l}\text { Complicated (.745) } \\
\text { Controversial (.463) } \\
\text { Easy to follow ( }\end{array}$ \\
\hline
\end{tabular}

Fig. 3. The possible relocations between factors. 
very common word for describing the art experience and can, therefore, be understood differently by different people. ${ }^{29}$ Also, the translation problems (the questionnaire was translated from English to Estonian) could be considered as a part of the challenges of international comparative research. ${ }^{30} \mathrm{Ad}$ ditional qualitative research is one way to overcome these issues. ${ }^{31}$ Thirdly, the overlaps could be caused by the selection of the performances.

\section{DISCUSSION AND INTERPRETATION}

The biggest overlaps are between the Aesthetic and Personally Challenging Factors and could be best explained by three performances - Purge, Career and $I r d, K$. - included in the survey, because these performances have high averages on the overlapping characteristics like exciting, inspiring, challenging etc. that can be included in both factors.

Purge was experienced as the most socially relevant (4.91), personally demanding (2.76), personally touching (4.27) and challenging (3.60) (all in the Personally Challenging Factor), but also very skilful (4.55) and impressive (4.63) (the Aesthetic Factor).
Career was found as the most full of new images (4.35) and most surprising (4.66), but also considered very impressive (4.58), skilful (4.40) (the Aesthetic Factor) and inspiring (4.23), exciting (3.47) and challenging (3.78) (the Personally Challenging Factor). Ird, $K$. is evaluated as the most impressive (4.85), skilful (5.02) and complete (4.50) (the Aesthetic Factor), but also most exciting (3.54) and inspiring (3.56) (the Personally Challenging Factor). Described very shortly at the beginning of the article, a closer insight into the storylines of these performances is needed.

Purge tells a story of an Estonian woman Aliide, who, out of love for her sister's husband, becomes a spy for the communist party and sends her sister and niece to Siberia. Aliide's story is shown as a series of flashbacks to her younger days, while she narrates the story to her sister's granddaughter Zara, a victim of human trafficking, who has escaped her 'pimp' and seeks shelter at her great aunt's farm. Even though some literary critics pointed out that Estonians were depicted as a one-dimensional nation representing sadness, revenge and rape, ${ }^{32}$ and that Oksanen reproduces the stereotype of the

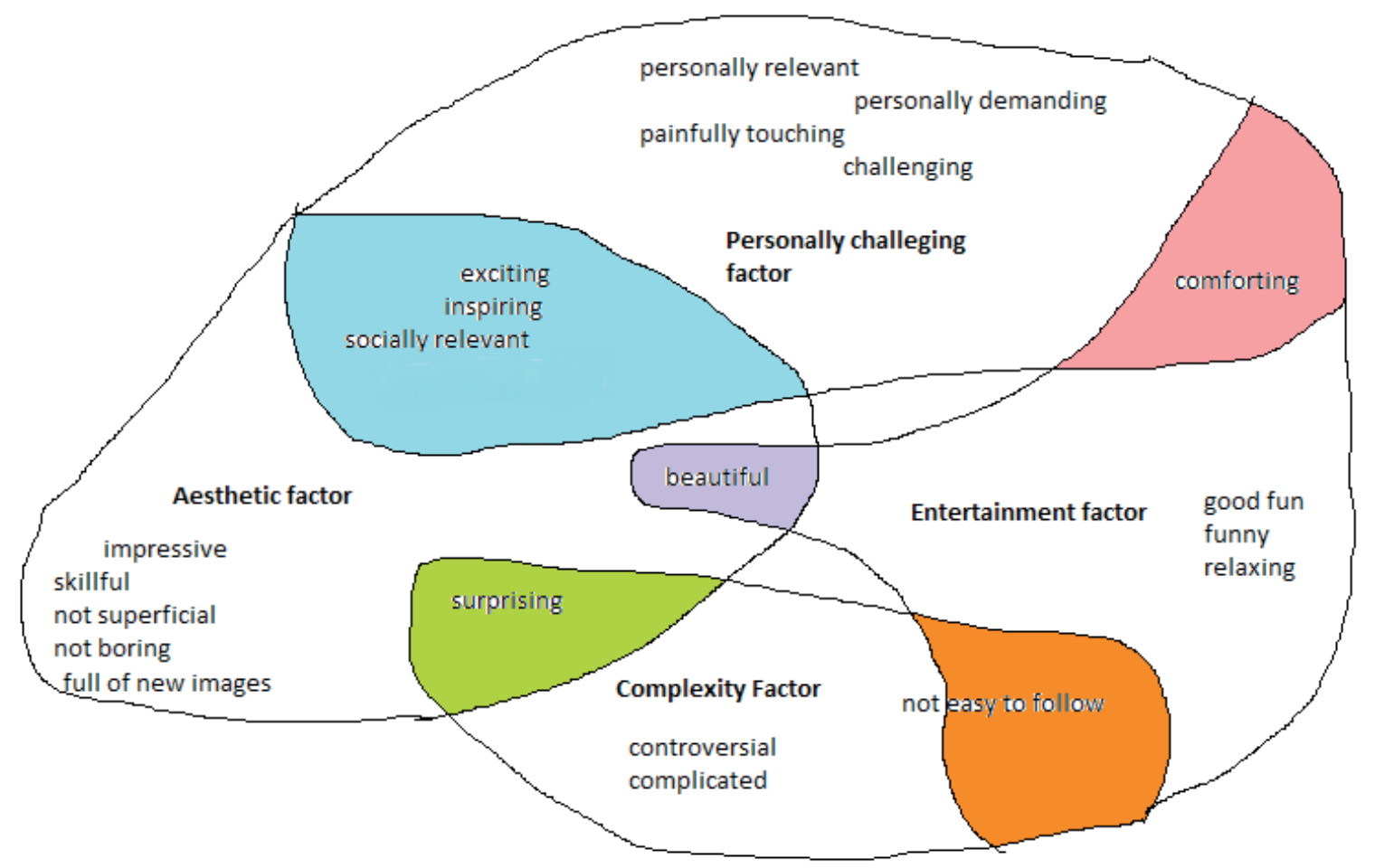

Fig. 4. The four factors of theatrical reception and the overlaps between them. 
Eastern-European woman who is 'easy', ${ }^{33}$ the performance was very well received by local audiences (it was not unusual for the Tartu audiences to give a standing ovation). The deportation of Estonians to Siberia is a subject that concerns almost every Estonian family and this could be one of the reasons the spectators found the performance socially relevant, personally touching and demanding and not in the least superficial, even though theatre critics pointed out the old fashioned style of the performance.

Generally speaking, the second performance, Career, is about living in the man-made world of laws and regulations and about the possibilities of rebelling against them in order to stay human inside. One of the protagonists, a university professor, Evald Liiv ("liiv" means "sand" in Estonian) has moved into the forest to live in a gravel-pit. His only friend is a mute, Pierrot like figure, Dj Zlava, who lives in an old theatre warehouse in the middle of all the props left in there. They are visited by a local government official and the mayor - both very young and recent students of Professor Liiv - who wish to throw them out of their current residence. The struggle of finding a balance between the obligations imposed on you by others and your own wishes in life is an on-going human dilemma and, therefore, something audiences could relate to. The young director, Uku Uusberg, created a unique atmosphere on the stage that was literally, and also symbolically, full of new images and beautiful to look $a t$, and was a combination of recognizable people and situations with a surprising twist, which made the performance enjoyable for both regular audiences and critics.

The societal issues - the possibilities of living in the Soviet Union - discussed in the performance $I r d, K$. about the famous theatre director Kaarel Ird are familiar to Estonians either from personal or indirect connections. The performance is considered very skilful and complete by the respondents and the good acting was also acknowledged: the actor playing the protagonist was awarded the prize for the best male actor in 2011. The excitement and inspiration in this performance could be seen by audiences thanks to the atmosphere that the performance created, combining - just as Career - a reality (which in this case was based on documented reality) and the twisted reality (which here could be perceived on two levels, i.e. the twisted reality created on the stage and the twisted reality that the Soviet Union produced in everyday life).

It is also important to point out that the same performances, which were previously mentioned, were also found to be the most complicated (Career, then Purge) and controversial (Career, Ird, K.). The performance which was considered the least easy to follow is Career followed by Purge but clearly for different reasons - Career being not easy to follow artistically and Purge thematically.

Even though the Conventionality Factor does not overlap with any other factors, it is important to point out that $I r d, K$. is found to be the second most recognizable performance among the eight performances and Purge the second most conventional.

The exemplary performances show that, from the perspective of the viewer, aspects like aesthetic and personal challenge as well as experiencing the performances as acted by professionals are often interrelated: being inspired, challenged and excited by the performance are all due to the reason that the performances are also personally touching and demanding and are performed by skilful performers. Purge, Ird, $K$. and Career prove that aesthetically challenging performances can be both thematically or artistically demanding for the viewer, but $s /$ he has to personally relate to the performance.

\section{CONCLUSION}

The differences between the theoretical input and empirical outcomes of the research prove that aesthetic experience is a faceted notion. As mentioned above, the performances that illustrated the complex relationship between the Aesthetic and Personally Challenging Factors were also considered the most complex. This means that even though the Complexity Factor is quite independent from other factors (and does not have many possible overlaps), the most complex and therefore challenging (as explained by Van Maanen) performances are also the ones that are considered the most professional, offer the greatest possibility for personal connection and bring forth emotional and cognitive engagement. Furthermore, as Purge and Ird, K. are also found to 
be the most recognizable (referring to comfortable experience because it does confirm the perception of the world), it can be concluded that there is also a connection between challenging and comfortable experience and they are not necessarily opposite to each other, as is suggested by Van Maanen. The recognisability of the performance does not mean that it cannot be controversial or complicated by form or content. These aspects can be studied more thoroughly with qualitative methods. Qualitative research enables us to understand the meaning of the dominants better and to open up the relationship between the different factors more precisely. 


\section{NOTES AND REFERENCES}

1 The research for this article has been supported by the Estonian Research Council (grant "Emergent Stories: Storytelling and Joint Sense Making in Narrative Environments"; PUT 192).

2 Willmar Sauter, "Who Reacts When, How and upon What: From Audience Surveys to the Theatrical Event" in Contemporary Theatre Review, vol. 12, no. 3, 2002, pp. 115-29.

3 Peter Eversmann, "The Experience of the Theatrical Event" in Theatrical Events. Borders, Dynamics, Frames, V. A. Cremona, P. Eversmann, H. Van Maanen, W. Sauter, J. Tulloch, eds., Rodopi, Amsterdam, New York 2004, pp. 139-74.

4 Marju Lauristin, Peeter Vihalemm, "'Tôe ja õiguse" etenduse vastuvôtt ja kunstielamuse kujunemise seaduspärasused" in Tammsaare ja meie. Nóukogude Eesti raamatukogundu, XII, ENSV kultuuriministeerium ja Fr. R. Kreutzwaldi nim. ENSV riiklik raamatukogu, Tallinn 1972, pp. 132-60.

5 Hans Van Maanen, How to Study Art Worlds. On the Societal Functioning of Aesthetic Values, Amsterdam University Press, Amsterdam 2009.

6 Sabine Boerner, Johanna Jobst, "Enjoying Theatre: The Role of Visitors' Response to the Performance" in Psychology of Aesthetics, Creativity, and the Arts, vol. 7, no. 4, 2013, pp. 391-408.

7 Global Changes, Local Stages: How Theatre Functions in Smaller European Countries, Andreas Kotte, Hans Van Maanen, Anneli Saro, eds., Rodopi, Amsterdam, New York 2009. The book focused on three aspects: the influences of globalization on a country's theatre system; how politics, policies and ideologies affect a country's theatre system; how these two aspects affect local theatre systems.

8 Hans Van Maanen, How to Study Art Worlds. On the Societal Functioning of Aesthetic Values, Amsterdam University Press, Amsterdam 2009.

9 The compratative research of the working group STEP is published in the international journal Amfiteater. Journal of Performing Arts Theory, vol. 3, no. 1-2.

10 Eversmann, op. cit., pp. 139-74.

11 Mihaly Csikszentmihalyi, Rick E. Robinson, The Art of Seeing. An Interpretation of the Aesthetic Encounter, J. Paul Getty Museum, Getty Centre for Education in the Arts, Los Angeles 1990. Csikszentmihalyi and Robinson asked experts of plastic arts to talk about their peak-ex- periences of art pieces. Eversmann conducted the same kind of qualitative survey with theatre experts, but included students as a non-expert reference group.

12 Van Maanen, op. cit., p. 188. The „experience of the form" is meant as the possible discrepency between forms and matter. For Van Maanen, it is the artistic communication where participants of the art experience "are asked to engage with foreign perceptions" and that "especially these types of communication hold investigation into the specific values and functions" (ibid, p. 189).

13 Ibid.

14 See Willmar Sauter, The Theatrical Event: Dynamics of Performance and Perception, University of Iowa Press, Iowa City, IA 2000 and Willmar Sauter, Eventness, a Concept of the Theatrical Event, STUTS, Stiftelsen för utgivning av teatervetenskapliga studier, Stockholm 2008 and Theatrical Events. Borders, Dynamics, Frames, V. A. Cremona, P. Eversmann, H. Van Maanen, W. Sauter, J. Tulloch, eds., Rodopi, Amsterdam, New York 2004.

15 Sauter, Eventness, a Concept of the Theatrical Event, op. cit.

16 The list of the characteristics was just one question in the questionnaire. Other questions of the questionnaire are not analysed in this particular article.

17 Eversmann, op. cit.

18 Van Maanen, op. cit.

19 Marline Lisette Wilders, Hedi-Liis Toome, Maja Šorli, Attila Sazbó, Antine Zijlstra, “"I Was Utterly Mesmerised". Audience Experiences of Different Theatre Types and Genres in Four European Cities" in Amfiteater. Journal of Performing Arts Theory, vol. 3, no. 1-2, pp. 304-43.

20 The statistics are based on the year 2013. Source: Estonian Theatre Agency webpage, statistika.teater.ee (accessed 10 December 2014).

21 The strategic development plan of the theatre Vanemuine for the years 2014-2018, http://www.vanemuine.ee/ wp-content/uploads/2014/10/Teater-Vanemuine-arengukava-2014-2018.pdf (accessed 1 June 2015).

22 The statistics are based on the year 2013. Source: Estonian Theatre Agency, op. cit.

23 The Estonian theatre renewal refers to the period starting with 1969 and lasting until the 1970s when young theatre directors like Evald Hermaküla (1941-2000) and Jaan Tooming (b. 1946) staged more experimental and physical performances that differed from the prevailing style of realism. See for example Jaak Rähesoo, Estonian Theatre, Estonian Theatre Union, Tallinn 2003. 
24 First written as a play and later modified into a novel, it won the Finlandia Prize (2008), the Runeberg Prize (2009), the Nordic Council Literature Prize (2010) and Prix Femina (2010). The novel has been translated into 38 languages.

25 Annotated SPSS output. Factor Analysis, IDRE, Institute for Digital Research and Education, http://www.ats. ucla.edu/stat/spss/output/factor1.htm (accessed 10 October 2014).

26 With principal axis factoring, the initial values on the diagonal of the correlation matrix are determined by the squared multiple correlation of the variable with the other variables (Annotated SPSS output. Factor Analysis, ibid). In the principal axis factoring method, we make an initial estimate of the common variance in which the communalities are less than 1 . This initial estimate assumes that the communality of each variable is equal to the square multiple regression coefficient of that variable with respect to the other variables. The principal axis factoring method is implemented by replacing the main diagonal of the correlation matrix (which consists of all ones) by these initial estimates of the communalities (Real Statistics Using Excel, http://www.real-statistics. $\mathrm{com} /$ multivariate-statistics/factor-analysis/principal-axis-method/, accessed 10 October 2014).

27 Annotated SPSS output. Factor Analysis, op. cit.

28 In addition the eight performances are aesthetically similar, all text based theate with storyline and character development.

29 If somebody wants to talk about a challenging or confronting experience in Estonian, one would rather use the words 'complicated', 'difficult', 'hard to understand', 'not easy to follow' (some of these words were also in the questionnaire).

30 See for example Tim May, Social Research: Issues, Methods and Process, McGraw-Hill, Open University Press, Maidenhead, New York 2011.

31 In-depth interviews and focus groups were also conducted during the STEP research but this analysis is beyond the scope of this article.

32 Rein Veidemann, "Oksaneni kuvand eestlastest on vastuoluline" in Postimees, 1 November 2010.

33 Piret Tali, "Kogu tôde Sofi O-st" in Eesti Päevaleht, 4 October 2010. 